\title{
STUDIES ON SOME NOVEL SILICA MOLECULAR SIEVES
}

\author{
R. P. GUNAWARDANE \\ Department of Chemistry, University of Peradeniya, Sri Lanka.
}

(Date of receipt : 10 September 1987)

(Date of acceptance : 09 February 1988)

\begin{abstract}
Four different silica end members of zeolites (zeosils) namely silica$Z S M-48$, silica ZSM-22, silica-ferrierite and silica-ZSM- 5 have been synthesized and their structural features and properties determined. Long chain polyamines act as templates for the formation of silica-ZSM-22 and silica-ZSM-48. The use of amines with side $\mathrm{NH}_{2}$ groups or straight chain amines at elevated temperatures, favours the formation of silica-ZSM-48. Ethylenediamine-boric acid pair acts as a template for silica-ferrerite formation while the use of highly branched tertiary amines leads to the formation of silica-ZSM-5. Available data indicate that these four zeosils are isostructural with the corresponding zeolites. These moleçular sieves contain 3-dimensional 4-connected network of corner

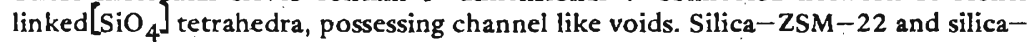
ZSM-48 contain $1 \mathrm{D}$ channel systems but the latter has wider channels. Silicaferrierite possesses 2D channels while silica-ZSM-5 possesses a $3 . \mathrm{D}$ channel system. All these frameworks are thermally stable upto $1000^{\circ} \mathrm{C}$, even after the removal of templates. They are hydrophobic, organophyllic and possess neither catalytic nor ion exchange properties.
\end{abstract}

\section{Introduction}

One of the major scientific and technological developments since the World War II has been the development of synthetic zeolites as molecular sieve adsorbents, ion exchangers and catalysts. More than sixty different zeolite framework topologies ${ }^{1}$ are known today and it is expected that many more will be synthesized in the near future.

A series of high silica zeolites has been synthesized in the presence of very small amounts of aluminium and they include $\mathrm{ZSM}-5, \mathrm{ZSM}-$ $11,{ }^{6} \mathrm{ZSM}-22,^{7} \mathrm{ZSM}-23,{ }^{12} \mathrm{ZSM}-48,{ }^{13}$ and $\mathrm{ZSM}-12 .^{8}$ High-silica zeolites are thermally very stable and are of considerable importance as industrial catalysts. ZSM-5 group of zeolites in particular is used as a catalyst $^{10}$ in the conversion of methanol to gasoline, ethylbenzene synthesis, xylene isomerization and toluene disproportionation. They also possess unusual hydrophobicity ${ }^{11}$ leading to potential applications in the separation of hydrocarbons from polar compounds such as water and alcohols.

Synthesis of pure silica (Al free) end-member of $\mathrm{ZSM}-5$ and ZSM -11 referred to as silicalite $1^{3}$ and silicalite $2^{2}$ respectively have been reported recently. Silica end members of zeolites have been given the name zeosils. ${ }^{9}$ This series of silica polymorphs constitute a hitherto unknown and a novel group of porous compounds, which are of considerable importance as organophillic, hydrophobic and thermally stable molecular sieves. This paper reports the synthesis, properties and structural features of three new 
zeosils namely silica-ZSM-48, silica-ZSM-22 and silica-ferrierite which are apparently isostructural with the corresponding zeolites ZSM-48, $\mathrm{ZSM}-22$ and silica-ferrierite respectively.

\section{Methods and Materials}

\subsection{Synthesis}

Silica molecular sieves have been crystallized hydrothermally from aqueous homogeneous $0.5 \mathrm{M}$ silicic acid solutions prepared by hydrolysing tetramethoxysilane, $\mathrm{Si}\left(\mathrm{OCH}_{3}\right)_{4}$, in water or in $2 \mathrm{M}$ aqueous ethylenediamine solution. The hydrolysis has been carried out under vigorous and continuous agitation. Special care has been taken to avoid any contamination by aluminium or any other cations.

The resulting silicic acid solutions were filled into silica glass tubes. After addition of organic amines (20\% by volume) or organic amine $(20 \%$ by volume) and $0.1 \mathrm{M}$ boric acid solution( $10 \%$ by volume), the tubes were sealed in air. The silica tubes were then subjected to thermal treatment in an oven at $160^{\circ}-200^{\circ} \mathrm{C}$ for a period ranging from 7 days to 3 months. The total pressure generated in the silica tubes is about 150 bar. The same synthesis procedure was adopted to synthesize all the zeosils described in this paper, except for different guest species employed(Table 2).

\subsection{Identification and analysis}

The crystallisation products were identified by optical microscopy and powder X-ray diffraction with $\mathrm{Cu} \mathrm{K}_{\propto}$ radiation. A Gandolfi camera had been used for the purpose of identification while a Phillips diffractometer had been used for the accurate measurement of $d$ values. Some crystals were subjected to electron diffraction by Phillips 802 electron microscope. Chemical analysis was carried out using a CAMECA Microprobe Analyzer. Boron contents were determined by using JY 38 Plasma spectrograph. Thermogravimetric analysis (TGA) was performed using a Dupont 1090 Thermal Analyzer.

\section{Results and Discussion}

\subsection{Zeosil formation}

Different polymorphs of silica such as quartz, cristobalite, keatite, etc., with high framework densities (Table 1) crystallize from aqueous silicic acid solutions under hydrothermal conditions in the absence of guest species. The presence of small gaseous molecules, short chain amines, cyclic amines, etc., results in the formation of clathrasils having lower framework densities and possessing polyhedral cavities or cages. ${ }^{4}$ The "windows" of these cages are too small for the free movement of guest molecules. On the other hand, 
long chan amines act as templates for the formation of zeolite-type aluminium free frameworks (zeosils) possessing channel like voids.

Table 1. Framework densities $\left(d_{f}\right) *$ of different silica polymorphs, clathrasils and zeosils

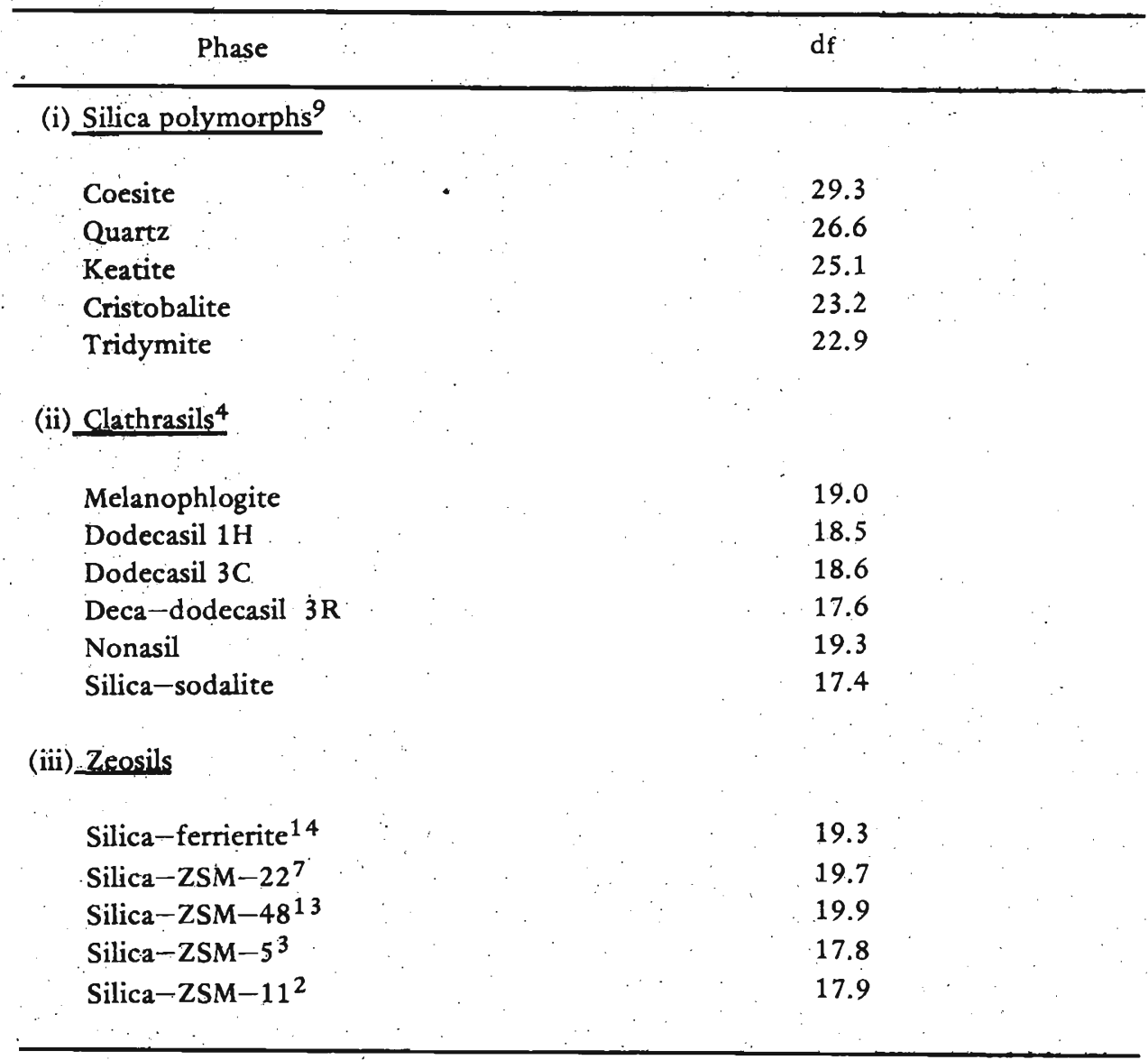

Note: * $\mathrm{d}_{\mathrm{f}}$ may be defined as number of $\mathrm{SiO}_{2}$ units per $1000 \mathrm{~A}^{3}$ in the structure. 
Four zeosils namely silica-ZSM-48, silica-ZSM-22, silica-ferrierite and silica-ZSM-5 (silicalite 1) have been crystallized in the present study. Successful guest species and the temperatures of synthesis are given in Table 2. Unbranched long chain amines such as diethylamines, 1-aminobutane at $160-180^{\circ} \mathrm{C}$ yield silica-ZSM-22. 1,4,8,11- tetraazaundecane, $1,5,8,12$ - tetraazadodecaneand 1,5,9,13-tetraazatridecane guest molecules also give the same zeosil at $160^{\circ} \mathrm{C}$ (Table 2). On the other hand, diethylenetriamine, triethylenetetramine, tetraethylenepentamine and 1,2-diamino: propane which contains a side- $\mathrm{NH}_{2}$ group, act as guests for the formation of silica -ZSM-48. Furthermore, 1,4,8,11-tetraazaundecane, 1,5,8,12tetraazadodecane and 1,5,9,13-tetraazatridecane too form silica-ZSM-48 at relatively higher temperatures $\left(180-200^{\circ} \mathrm{C}\right)$.

It was not possible to synthesize silica-ferrierite using only the polyamines as the guest species. Presence of boric acid was found to be essential for the crystallization of silica-ferrierite. Of the guest species attempted ethylenediamine-boric acid pair was found to be the most efficient guest system for the formation of silica-ferrierite. Highly branched amines such as triethylamine, tripropylamine, tributylamine as well as long chain polyamines-boric acid pairs act as templates for the formation of silica$\mathrm{ZSM}-5$.

It is evident that amines having relatively short chains, particularly at lower temperatures, favour the formation of silica-ZSM-22. Elevation of temperature or the increase of width of amine chains by the introduction of a side $-\mathrm{NH}_{2}$ group lead to the formation of silica-ZSM-48 possessing relatively wide $1 \mathrm{D}$ channel systems (Table 4). Thus, it is apparent that increase in width of the guest molecule and the high mobility of atoms and molecules at elevated temperatures favour the formation of wide channel 1D zeosils. Highly branched tertiary amines form silica-ZSM-5 because these amines could readily be accomodated in a $3 \mathrm{D}$ channel system with a possible location of their tertiary $\mathrm{N}$ atoms at the intersection points with the chains protruding into the channel voids.

It has been observed that in the presence of polyamines and boric acid, zeosils with 2D and 3D channel systems are formed. Analytical data of these as-synthesized as well as ignited products suggest that boron is not present in the framework but it is almost exclusively associated with the guest species. Thus, ethylenediamine-boric acid pair can be considered as the effective template for silica-ferrierite synthesis. It is likely that in zeosils synthesized in the presence of amine-boric acid pairs, the $\mathrm{B}-\mathrm{N}$ groups are located at the channel intersections with side chains stretching into the cavities. 
Table 2. Successful guest species and the temperatures for zeosil synthesis

\begin{tabular}{|c|c|c|c|}
\hline Zeosil & $160^{\circ} \mathrm{C}$ & $\begin{array}{l}\text { Guest species } \\
180^{\circ} \mathrm{C}\end{array}$ & $200^{\circ} \mathrm{C}$ \\
\hline $\begin{array}{l}\text { Silica- } \\
\qquad \text { ZSM-48 }\end{array}$ & $\begin{array}{l}\text { Diethylenetri- } \\
\text { amine } \\
\text { Triethylenetetr- } \\
\text { amine } \\
\text { Tetraethylene- } \\
\text { pentamine } \\
1,2 \text {-diamino- } \\
\text { propane }\end{array}$ & $\begin{array}{c}\text { Diethylenetri- } \\
\text { amine } \\
\text { Triethylenetetr- } \\
\text { amine } \\
\begin{array}{c}\text { Tetraethylene- } \\
\text { pentamine } \\
1,2-\text { diamino- } \\
\text { propane } \\
1,3-\text { diamino- } \\
\text { propane }\end{array} \\
\begin{array}{c}1,4,8,11 \text {-tetraaza- } \\
\text { undecane }\end{array} \\
\begin{array}{c}1,5,8,12 \text {-tetraaza- } \\
\text { dodecane }\end{array} \\
1,5,9,13 \text {-tetraaza- } \\
\text { tridecane }\end{array}$ & $\begin{array}{c}\text { Diethylenetri- } \\
\text { amine } \\
\text { Triethylenetetr- } \\
\text { amine } \\
\text { Tetraethylene- } \\
\text { pentamine } \\
1,4,8,11-\text { tetra- } \\
\text { azaundecane } \\
1,5,8,12-\text { tetra- } \\
\text { azadodecane } \\
1,5,9,13 \text {-tetraaza- } \\
\text { tridecane }\end{array}$ \\
\hline $\begin{array}{l}\text { Silica- } \\
\text { ZSM-22 }\end{array}$ & $\begin{array}{l}\text { Diethylamine } \\
1 \text {-aminobutane } \\
1,3 \text {-diamino- } \\
\text { propane } \\
1,4,8,11 \text {-tetraaza- } \\
\text { undecane } \\
1,5,8,12 \text {-tetraaza- } \\
\text { dodecane } \\
1,5,9,13 \text {-tetraaza- } \\
\text { tridecane }\end{array}$ & $\begin{array}{l}\text { Diethylamine } \\
1 \text {-aminobutane }\end{array}$ & - \\
\hline $\begin{array}{l}\text { Silica- } \\
\text { ferrierite }\end{array}$ & $\begin{array}{l}\text { Ethylenediamine } \\
+ \text { Boric acid }\end{array}$ & $\begin{array}{l}\text { Ethylenediamine } \\
\quad+\text { Boric acid }\end{array}$ & \\
\hline $\begin{array}{l}\text { Silica- } \\
\text { ZSM-5 }\end{array}$ & $\begin{array}{l}\text { Triethylamine } \\
\text { Tripropylamine } \\
\text { Tributylamine } \\
\text { Triethylenetetra- } \\
\text { mine + Boric acid } \\
\text { Tetraethylenepen- } \\
\text { amine + Boric acid }\end{array}$ & $\begin{array}{l}\text { Triethylamine } \\
\text { Tripropylamine } \\
\text { Tributylamine } \\
\text { Triethylenetetra- } \\
\text { mine + Boric acid } \\
\text { Tetraethylenepent- } \\
\text { amine + Boric acid }\end{array}$ & $\begin{array}{l}\text { Diethylenetriamine } \\
\quad+\text { Boric acid } \\
\text { Triethylenetetra- } \\
\text { mine + Boric acid } \\
\text { Tetraethylenepent- } \\
\text { amine }+ \text { Boric acid } \\
\therefore\end{array}$ \\
\hline
\end{tabular}




\subsection{Structural features}

$\mathrm{X}$-ray powder patterns of silica-ZSM-48, silica-ZSM-22 and silicaferrierite were indexed on the basis of orthorhombic cells and the least square refinement gave accurate unit cell parameters. These unit cell parameters are compared with the corresponding zeolites in Table 3. For completeness $\mathrm{ZSM}-5$ and silica- $-\mathrm{ZSM}-5$ are also included in the table. In general there is a slight decrease in all unit cell parameters with respect to their values in the corresponding zeolites. This is expected due to the complete replacement of larger $\mathrm{Al}$ by smaller $\mathrm{Si}$ in zeosils.

$\mathrm{X}-$ ray powder patterns of these products were very similar to those of the corresponding zeolites indicating that they are isostructural, while microprobe analysis of the products confirmed the presence of only silicon and absence of aluminium in the frameworks. Thus, it is apparent that all these zeosils contain 3-dimensional 4-connected networks of $\mathrm{SiO}_{4}$ tetrahedra possessing channel like voids.

\subsection{Silica-ZSM-48}

The cell parameters of silica-ZSM-48 were fixed from both $\mathrm{X}-$ ray powder diffraction and electron diffraction data. Approximate values for $a^{*}, b^{*}$ and $c^{*}$ fromelectron diffraction patterns of the (hol)-and(hKO)-reciprocal lattices of silica-ZSM-48 were used to compute approximate direct cell parameters. The electron diffraction patterns are shown in Figure 1. The cell parameters were refined to $a=1421(4), b=20.09(5)$ and $c=$ $8.40(3) \AA$, using the best-resolved peaks in the powder $\mathrm{X}$-ray pattern. Powder reflections indicate $C$ or I centering suggesting Immm, Imma, $\mathrm{Cmcm}$ and $\mathrm{Cmmm}$ symmetries. All specimens investigated by TEM showed weak reflections indicating the space groups Pmnm or P2 $1 \mathrm{~nm}$. Disregarding the weak reflections the space group Immm was found to be the most plausible. Twinning of silica-ZSM-48 is a common feature and the twin plane is perpendicular to [001]. 


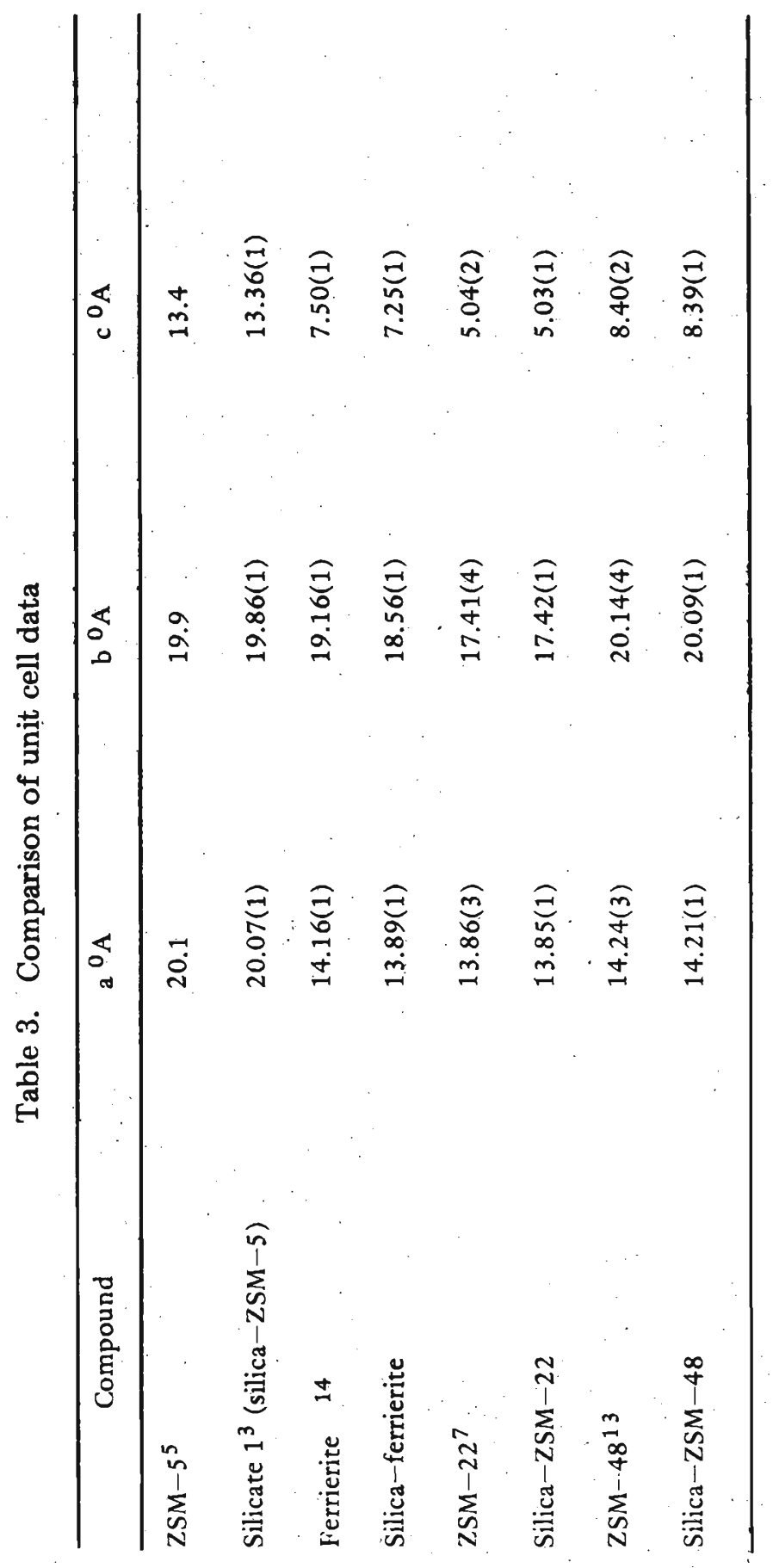



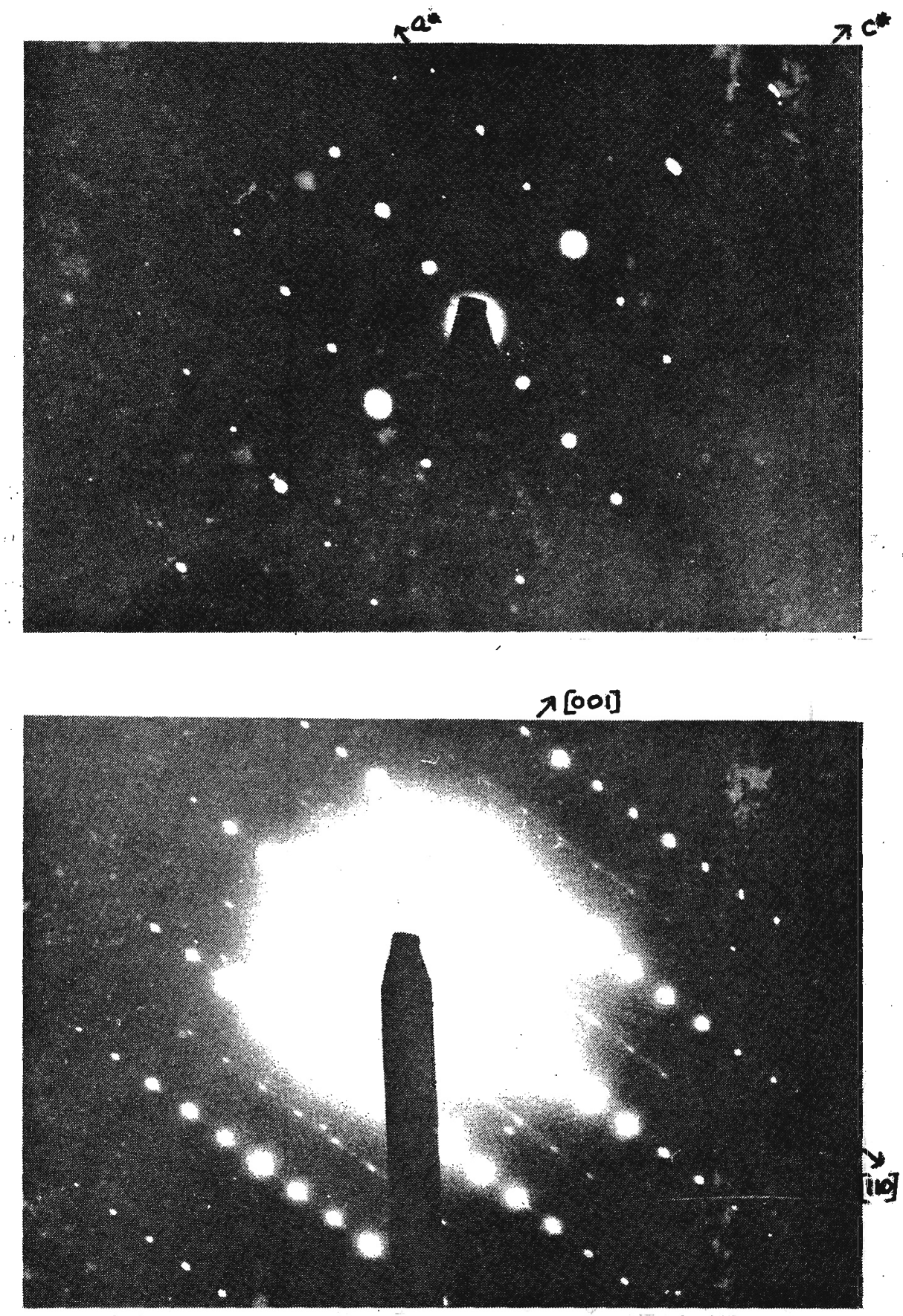

Figure 1 Electron diffraction pattern of silica-ZSM-48 (a) hol recriprocal lattice, (b) hko reciprocal lattice. 
Considering the structures of the zeolites, $\mathrm{ZSM}-48^{13}$ and ferrierite ${ }^{14}$ it may be possible to propose a structure for silica-ZSM-48. A structure based on ferrierite sheets linking via oxygen atoms located on mirror planes and consisting of $1 \mathrm{D}$ channel system may be visualized for this zeosil. Figure 2 shows a projection of the structure along[001].

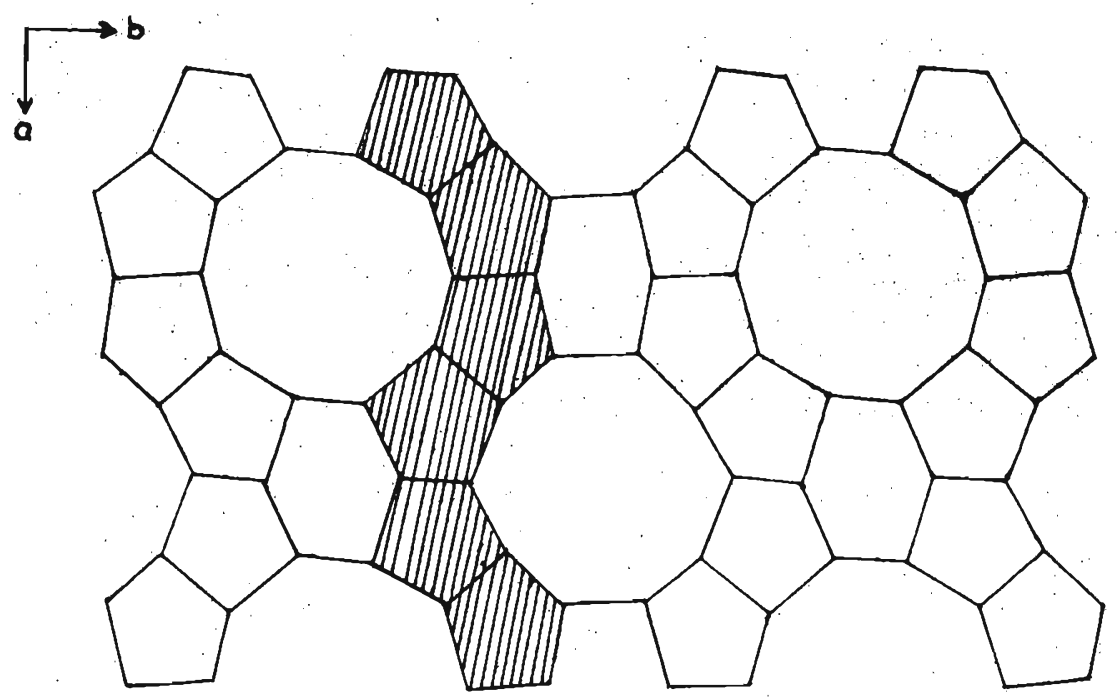

Figure 2 Projection of the structure of silica-ZSM-48 along (001). One chain of zig-zag edge-sharing $5-$ membered rings is shaded.

The framework is composed of 5-,6- and 10- menbered rings of $\left[\mathrm{SiO}_{4}\right]$ No 4-rings are present. Edge-sharing 5-membered rings of $\mathrm{SiO}_{4}$ tetrahedra form sinusoidal chains which traverse along a direction producing elliptical $(\mathrm{d} \sim 5.3 \times 5.6 \AA) 10-$ membered ring openings. The $10-\mathrm{T}-$ ring channels (Figure 3 ) are not interconnected and therefore, represent a $1 D$ channel system parallel to[001]. This channel system is similar in size to the straight channels ${ }^{5}$ of the ZSM-5 framework. 


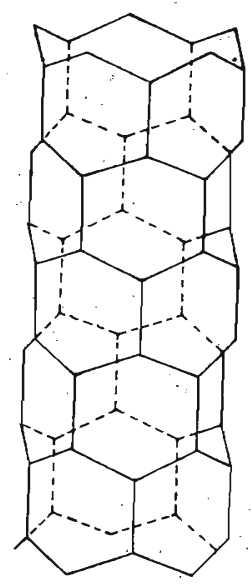

Figure $3 \cdots$ Representation of a 10-ring 1D channel in silica-ZSM-48.

\subsection{Silica-ZSM-22}

Refinement of cell parameters using the indexed powder pattern by least square method gave unit cell parameters as $a=13.85$ (1), $b=17.42(1)$ and $c=5.03(1)$ (hkl) reflections with $\mathrm{h}+\mathrm{k} \neq 2 \mathrm{n}$ and (hol) reflections with $1 \neq 2 \mathrm{n}$ were absent indicating a $C$ centred lattice. Similar to silica-ZSM-48, twinning is a common feature in silica-ZSM-22 and the twin plane is often [110].

As in the case of silica- $\mathrm{ZSM}-48$, the structure consists of $5-, 6-$ and 10- membered rings of $\mathrm{SiO}_{4}$ tetrahedra. Figure 4 gives a projection of the structure along[001].Zig - zag chains of 5- T-rings are running along the a direction forming $1 \mathrm{D}, 10-\mathrm{T}$-ring channels parallel to $c$ axis. The channels are considerably smaller $(\mathrm{d} \sim 4.7 \times 5.5 \AA)$ than those in silicaZSM-48 (Table 4).

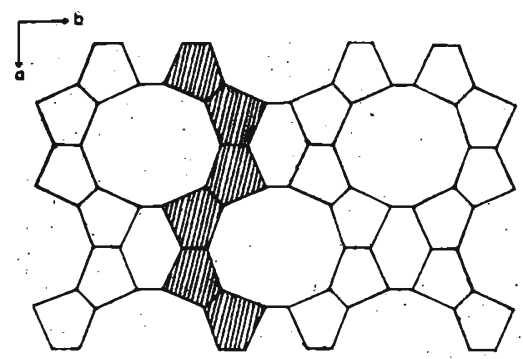

Figure 4 Projection of the structure of silica-ZSM-22 along (001). One chain of zig-zag 5 -membered rings is shaded. 


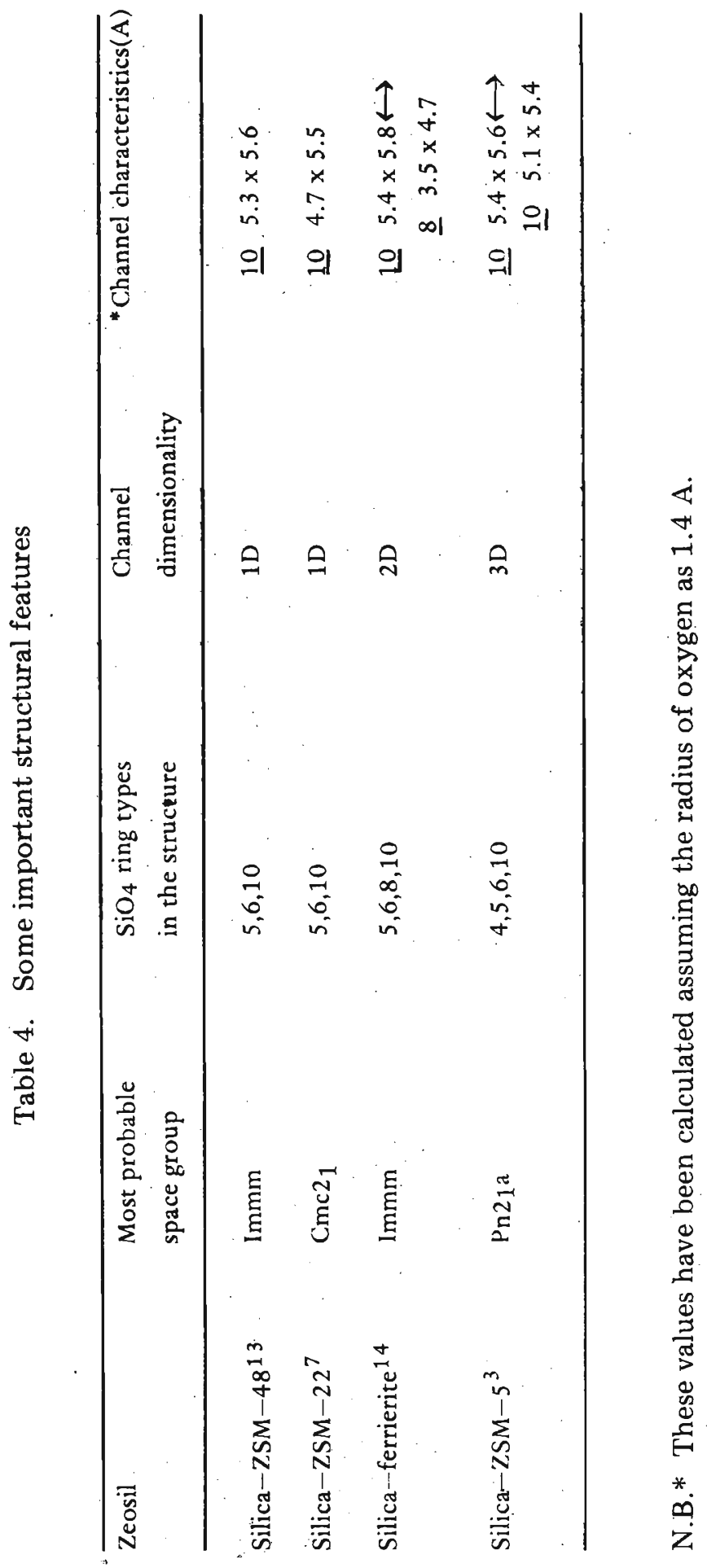


Comparison of dimensions of different guest molecules with the channel dimensions of silica- $\mathrm{ZSM}-22$ indicates that only unbranched aliphatic chains can occupy the channels without appreciable distortion of the framework or the guest chains. It can be shown that the long chain amines almost completely fill the available space within the channels (Figure 6).

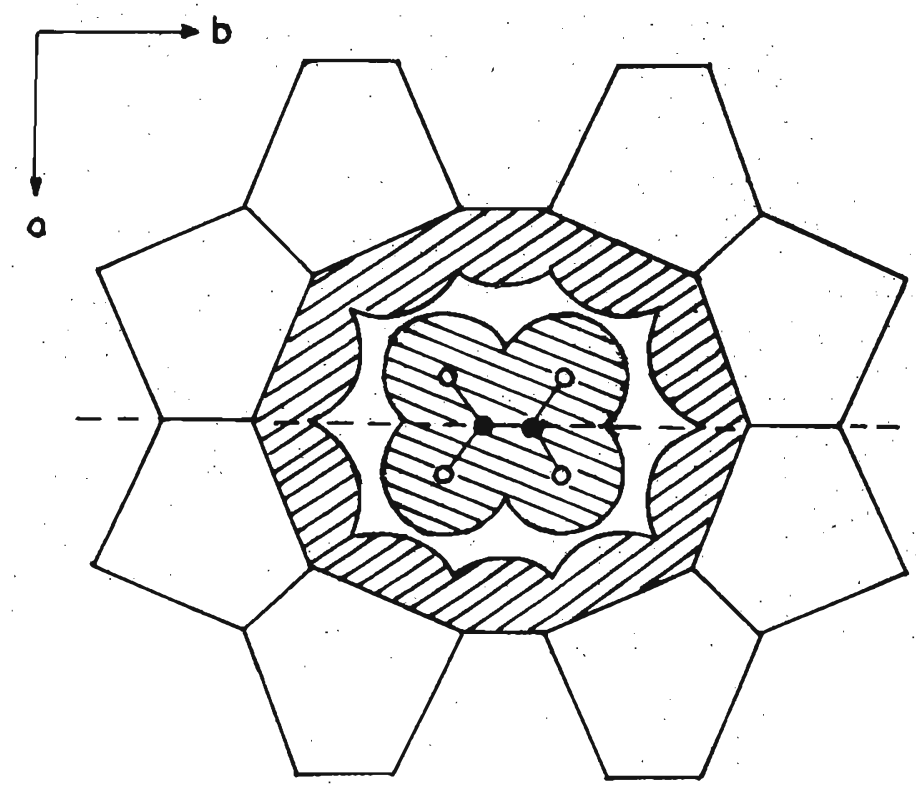

Figure 6 Cross section of a 10-T-ring channel of silica-ZSM-22 along (001) showing the position of a guest molecule.

\subsection{Silica-ferrierite}

Least square refinement of the powder data gave unit cell parameters as $a=13.89(1), b=18.56(1)$ and $c=7.25(1)$. The powder pattern was very similar to naturally occurring ferrierite. ${ }^{14}$ The most probable space group was found to be Immm.

The framework consists of 5-,6-,8- and 10-membered rings of $\left[\mathrm{SiO}_{4}\right]$ tetrahedra. The structure is characterized by the presence of zig-zag chains of 5-membered rings parallel to[001] forming a 2D channel system. The main channels are running along [001] with 10-T-ring openings $(\mathrm{d} \sim 5.4 \times 5.8 \AA)$ while side channels with $8-\mathrm{T}$-ring openings $(\mathrm{d} \sim 3.5 \mathrm{x}$ $4.7 \AA$ ) are parallel to [010l, Figure 5 shows the projection of the structure along [001]. 


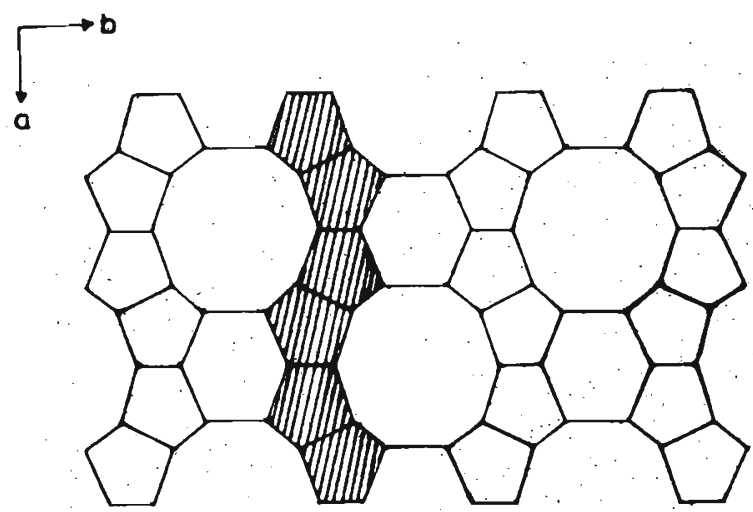

Figure 5 Projection of the structure of silica-ferrierite along (001). One chain of zig-zag 5 -membered rings is shaded.

Main structural features of silica-ZSM--48, silica-ZSM-22 and silica-ferrierite are compared with those of silica-ZSM-5 (silicalite 1$)^{3}$ in Table 4. Silica-ZSM-5 framework contains 4-membered rings in addition to $5-, 6-$ and $10-$ membered rings of $\left[\mathrm{SiO}_{4}\right]$ The framework is traversed by a 3D channel system containing straight and sinusoidal channels with 10-T-ring openings. The channel openings are elliptical with free diameter intermediate between those of large pore (faujasite type) and small pore (Linde type A) zeolites.

\subsection{Thermal behaviour}

Silica-ZSM-5, silica-ZSM-48, silica-ZSM-22 and silica-ferrierite frameworks were found to be thermally stable up to about $1000^{\circ} \mathrm{C}$. A continuous weight loss has been observed in TGA up to about 900$1000^{\circ} \mathrm{C}$ at which temperature a constant weight has been obtained. During thermal treatment the organic guest species are decomposed, oxidized and removed from the channels resulting in guest-free frameworks. The framework is unaffected even after prolonged heat treatment at $900^{\circ} \mathrm{C}$, as shown by powder $\mathrm{X}$-ray patterns. However, in the temperature range 1000$1100^{\circ} \mathrm{C}$ the silica frameworks transform slowly to the thermodynamically stable phase, cristobalite.

TGA of silica-ZSM -5 shows that, the weight loss occurred in two stages in the temperature range $300-800^{\circ} \mathrm{C}$ indicating possible self-blocking at the channel intersections. Similar but relatively less self-blocking is observed in silica-ferrierite. For instance weight loss of silica-ferrierite in TGA occurs in 2 stages although the two stages are not clearly visible unlike in the case of silica-ZSM-5. Fragments of the guest species located at the channel intersections may be responsible for this blocking. However, in silica-ZSM-48 and silica-ZSM- 22 with $1 \mathrm{D}$ channel systems the selfblocking is not evident and their weight loss is gradual and continuous in the temperature range $350-800^{\circ} \mathrm{C}$. 


\subsection{Properties and applications}

Intracrystalline pore volumes of silica-ZSM-5 and silica-ferrierite are about $33 \%$ and $24 \%$ respectively while both silica-ZSM-48 and silicaZSM- 22 are about $20 \%$ porous. No water molecules have been observed to be located in these channels suggesting that they are hydrophobic. Furthermore, it has been observed that the guest-free frameworks have greater affinity for organic molecules. For example traces of methanol, propanol and hexane have been removed from water by silica-ZSM- 5 synthesized in the present study. Thus, these silica molecular sieves are potentially useful in the separation of organic compounds from water.

Furthermore, it has been observed that the guest-free frameworks have a greater affinity for organic molecules. A series of aqueous solutions have been prepared using 5-10 ppm of (i) methanol, (ii) propanol and (iii) hexane, with deionized water. To these solutions guest-free silica- $\mathrm{ZSM}-5$ has been added and equilibrated for 6 hours. The contents of methanol, propanol and hexane have been estimated using High Performance Liquid Chromatography (HPLC) before and after this treatment. The solutions obtained after equilibration with silica-ZSM-5 followed by filtration, were completely free of any organic compounds showing that these molecular sieves are capable of separating organic compounds from water.

Table 5. Framework decomposition temperatures of some zeolites and zeosils

\begin{tabular}{ll}
\hline Zeolite/Zeosil & $\begin{array}{l}\text { Framework decomposition } \\
\text { Temperature (approximately) }\end{array}$ \\
\hline Ferrierite $^{14}$ & $960^{\circ} \mathrm{C}$ \\
${\text { ZSM }-22^{7}}^{7}$ & $940^{\circ} \mathrm{C}$ \\
Silica-ferrierite & $1100^{\circ} \mathrm{C}$ \\
Silica-ZSM-22 & $1060^{\circ} \mathrm{C}$ \\
\hline
\end{tabular}

As mentioned earlier they are thermally very stable in comparison (Table 5) with the corresponding zeolites. The frequent occurrence of 5 -membered rings of $\left[\mathrm{SiO}_{4}\right]$ tetrahedra throughout these structures may be responsible for the high thermal stability of these zeosils. In addition, they are stable to most mineral acids except HF. However, since these molecular sieves have electrically neutral frameworks, neither catalytic activity nor cation exchange properties may be expected. Nevertheless, they may perhaps be employed as catalyst carriers in industrial catalysis. 


\section{Acknowledgement}

Most of the experimental work described in this paper has been carried out at the Institute of Mineralogy, Kiel University in West Germany with the financial assistance from Alexander von Humboldt-Stiftung. Author wishes to thank Prof. F. Liebau and Dr. H. Gies for their assistance in the experimental work.

\section{References}

1. BARRER, R.M. (1983) J. Inclusion Pbenomena, $1: 105$.

2. BIBBY, D.M., MILESTONE, N.B. \& ALDRIDGE, L.P. (1979) Nature, $280: 664$.

3. FLANIGEN, E.M., BENNETT, J.M., GROSE, R.W., COHEN, J.P., PATTON, R.L., KIRCHNER, R.M. \& SMITH, J.V. (1978) Nature, 271 : 512.

4. GUNAWARDANE, R.P., GIES, H. \& LIEBAU, F. (1987) Z. Anorg. Allg. Cbem. 546: 189.

5. KOKOTAILO, G.T., LAWTON, S.L. \& OLSON, D.H. (1978) Nature, 272 : 437.

6. KOKOTAILO, G.T., CHU, P. \& LAWTON, S.L. (1978) Nature, 275 : 119.

7. KOKOTAILO, G.T., SCHLENKER, J.L., DWYER, F.G. \& VALYOCSIK. E.W. (1985) Zeolites, $5: 349$.

8. LAPIERRE, R.B., ROHRMAN, A.C., SCHLENKER, J.L., WOOD, J.D., RUBIN, M.K. \& ROHRBAUGH, W.J. (1985) Zeolites, 5 : 346.

9. LIEBAU, F., GIES, H., GUNAWARDANE; R.P. \& MARLER, B. (1986) Zeolites, $6: 373$.

10. MEISEL, S.L., MCCULLOGH, J.P., LECHTHALER, C.H. \& WEISZ, P.B. (1976) Chem. Tecbnol. $6: 86$.

11. OLSON, D.H., HAAG, W.O. \& LAGO, R.M. (1980) Journal of Catalysis, 61 : 390.

12. ROHRMAN, A.C., LAPIERRE, R.B., SCHLENKER, J.L., WOOD, J.D., VALYOCSIK, E.W., RUBIN, M.K., HIGGINS, J.B. \& ROHRBAUGH, W.J. (1985) Zeolites, 5 : 352.

13. SCHLENKER, J.L., ROHRBAUGH, W.J., CHU, P., VALYOCSIK, E.W. \& KOKOTAILO; G.T. (1985) Zeolites, 5 : 355.

14. WISE, W.S. \& TSCHERNICH, R.W. (1976) American Mineralogist, 61 : 60. 